\title{
Effects of Abscisic Acid on the Sprouting of Aerial Tubers of Begonia evansiana and Dioscorea batatas
}

\author{
by Tohru HASHImoto* and Saburo TAMURA*
}

\author{
Received September 14, 1968
}

\begin{abstract}
d-Abscisic acid (ABA) inhibited the sprouting of aerial tubers of B. evansiana, which had been vernalized, at concentrations from $3 \times 10^{-6}$ to $10^{-5} \mathrm{M}$. In some experiments it caused promotion of sprouting at $10^{-6} \mathrm{M}$. Though weaker, similar effects were observed with cut aerial tubers of $D$. batatas. Intact tubers of this species did not respond to ABA.

The low responsiveness of $D$. batatas to added ABA may not originate from its inactivation or decomposition, since the ABA added was recovered without any change.

ABA was ineffective in inducing the formation of aerial tubers on $B$. evansiana plants under long-day conditions.
\end{abstract}

Begonia evansiana has been shown to form aerial tubers at axils on short-day induction ${ }^{1)}$. At maturity the tubers are in dormancy, which is broken by a cold treatment at $2-8^{\circ}$ for about a month ${ }^{2}$. Dioscorea batatas also forms aerial tubers in early autumn, which are in dormancy and released from it by cold treatment. In contrast to buds and seeds of other species which experience dormancy, the tubers of the above-stated plants show a unique mode of dormancy as intensified by gibberellin treatment ${ }^{3}$.

Recently we have isolated abscisic acid (ABA) from dormant aerial tubers of Dioscorea as a substance probably responsible for the dormancy ${ }^{4}$, but have not succeeded yet in showing the occurrence of the acid in Begonia tubers. In this paper we report effects of ABA on the formation of aerial tubers in Begonia as well as on the sprouting of vernalized aerial tubers of Begonia and Dioscorea.

Physiological and biochemical functions of ABA are being investigated extensive$1 \mathrm{y}^{5)}$, and particularly it has been shown that ABA inhibits germinations of lettuce ${ }^{6}$, $\operatorname{ash}^{7)}$, peach ${ }^{8)}$, and hazel ${ }^{9)}$ seeds, and sprouting of potato tubers ${ }^{10)}$. The acid has also been reported to suppress the cytokinin-induced swelling of Begonia aerial tubers ${ }^{11}$.

\section{Materials and Methods}

Begonia tuber formation. From plants of Begonia evansiana Andr. grown in a shade in a garden, about $20 \mathrm{~cm}$ long shoots with the apex were excised, inserted in $180-\mathrm{ml}$ milk bottles (two cuttings each) filled with half-strength Hoagland's nutrient solution, and kept in the original habitat of the plants. Throughout this experiment the natural day-length was extended by illuminating from the dusk to $10 \mathrm{p} . \mathrm{m}$. with a 100 -watt incandescent filament lamp hanged $50 \mathrm{~cm}$ above the plants. The culture solution was

* Department of Agricultural Chemistry, the University of Tokyo, Bunkyo-ku, Tokyo, 113, Japan. 
renewed once a week. Ten days later when the cuttings formed roots, treatment of ABA started. Each axil and apex of the cuttings were treated with $10 \mu \mathrm{l}$ of $100 \mu \mathrm{g} / \mathrm{ml}$ d, 1-ABA solution dissolved in 50\% aqueous acetone containing $0.025 \%$ Tween 20 . Control lot was similarly treated with plain Tween-aqueous acetone.

Sprouting of Begonia tubers. Aerial tubers of B. evansiana were harvested in October, 1967 , and stored in polyethylene bags at about $5^{\circ}$ until use, During the storage the tubers were vernalized. At the time of use tubers were partially sterilized in 500 times diluted "Osban" (10\% benzalkonium chloride solution, Takeda Chemical Ltd., Osaka) for $30 \mathrm{~min}$, thoroughly rinsed with tap water and cut into half. The upper halves were placed on thin cotton layer in $9-\mathrm{cm}$ petri dishes moistened with $8 \mathrm{ml}$ of distilled water or d-ABA water solution.

In another experiment, tubers treated with "Osban" were further sterilized with $0.5 \%$ sodium hypochlorite solution for $10 \mathrm{~min}$, rinsed with sterile water and cut into half. A single upper half was placed on a cotton piece in an aseptic test tube $(1.5 \mathrm{~cm} \times 10 \mathrm{~cm})$ moistened with $0.5 \mathrm{ml}$ of $\mathrm{ABA}$ solution or water. On the 9th day of culture $0.4 \mathrm{ml}$ of ABA solution or water was supplemented aseptically.

Sprouting of Dioscorea tubers. Aerial tubers of Dioscorea batatas Decne. harvested in October, 1967, were stored in the same manner as Begonia tubers. At the time of use tubers were sterilized likewise and the apical part of tubers, $10-14 \mathrm{~mm}$ in diameter and $3-5 \mathrm{~mm}$ in height, was excised and placed in test tubes (the same size as above). Since the cut surface of Dioscorea tubers was large, $1 \mathrm{ml}$ of $1 \%$ agar was used as a substitute for cotton piece so as to secure the cut surface to contact the culture bed. ABA was added to the agar.

For intact tubers $20 \mathrm{~g}$ of air-dried garden soil was placed in each 9 -cm petri dish, to which $9.1 \mathrm{ml}$ of water was added to give a moisture of $60 \%$ water holding capacity of the soil. The dishes thus prepared were autoclaved. Ten tubers treated with "Osban" were placed on the soil of dishes so that the lower part (approximately 1/4) of each tuber was buried. This culture method was shown to be the best for intact aerial tubers. d-ABA was dissolved at 400,40 , and $4 \mu \mathrm{g} / \mathrm{ml}$ in water containing $0.05 \%$ Tween 20 , and $2.5 \mu \mathrm{l}$ of the solutions was applied with a microsyringe to each tuber apex on the first and second days of incubation.

Incubation of $A B A$ with Dioscorea tuber tissues. Aerial tubers stored at $5^{\circ}$ for 7 months (until June of 1968) were cut into slices, 0.5-1 mm thick, and $2 \mathrm{~g}$ in fresh weight of slices were placed in a $30-\mathrm{ml}$ Erlenmeyer flask containing $5 \mathrm{ml}$ of $0.1 \mathrm{M}$ tris- $\mathrm{HCl}$ buffer ( $\mathrm{pH} 7.2$ ) with or without the addition of $2 \mu \mathrm{g} / \mathrm{ml} \mathrm{d}-\mathrm{ABA}$, and incubated by shaking at $120 \mathrm{cycles} / \mathrm{min}$ at $26.5^{\circ}$ for $17.5 \mathrm{hrs}$. At the end of the incubation the tissues were killed by adding concentrated phosphoric acid until the $\mathrm{pH}$ of the media was 2.0. The media and slices were then extracted altogether with three $10 \mathrm{ml}$ portions of ether to determine the recovery of ABA added.

Thin-layer chromatography. Kieselgel G plates were used throughout. Among three solvent systems tested, I was the best to separate ABA from gibberellins, and III was preferable for discrimination of ABA from indole-3-acetic acid as shown in Table 1. Based on the result of Thomas et al. ${ }^{12}$ that gibberellins interfere with determination of ABA by the Avena coleoptile section test rather than IAA, solvent system I was used for the separation of the ABA extract mentioned above. Authentic ABA on a chromatogram was detected as yellow spot with iodine vapor.

Optical rotatory dispersion. Sample was dissolved in $5 \mathrm{ml}$ of ethanol containing $0.01 \mathrm{~N}$ hydrochloric acid, and its ORD was recorded with a spectropolarimeter (Japan Spectroscopic Ltd., ORD/UV-5). 
Table 1. Rf values in thin-layer chromatography of growth regulating compounds.

\begin{tabular}{lccc}
\multicolumn{1}{c}{ Compounds } & I & $\begin{array}{c}\text { Solvent system } \\
\text { II }\end{array}$ & III \\
\hline Abscisic acid & .27 & .83 & .57 \\
Deoxygibberellin C & .26 & .86 & .69 \\
Gibberellin $A_{7}$ & .21 & .78 & .56 \\
Gibberellin $\mathrm{A}_{9}$ & .42 & - & - \\
Gibberellin $\mathrm{A}_{20}$ & - & .80 & .58 \\
Indole-3-acetic acid & .31 & .67 & .43
\end{tabular}

Solvent system I, benzene/ethyl acetate/acetic acid (75:20:5v/v); II, n-propanol/ ammonium hydroxide $(15 \mathrm{~N}) /$ water $(6: 1: 2 \mathrm{v} / \mathrm{v})$; III, n-propanol/n-butanol/ammonium hydroxide $(15 \mathrm{~N}) /$ water $(6: 2: 1: 2 \mathrm{v} / \mathrm{v})$. Developed $12.5 \mathrm{~cm}$ at about $20^{\circ}$.

Avena coleoptile section test. Seedlings were grown under a week red light at $25^{\circ}$ for about $72 \mathrm{hrs}$., and a single 5 -mm section was cut $4 \mathrm{~mm}$ below the tip from a $25 \mathrm{~mm}$ long coleoptile without the first decapitation. Sections were cultured on $2.5 \mathrm{ml}$ of medium containing $1 \mu \mathrm{g} / \mathrm{ml}$ IAA, $2 \%$ sucrose, and various concentrations of test sample for $18 \mathrm{hrs}$. at $25^{\circ}$.

Abscisic acid $(A B A)$. d-ABA was isolated from $D$. batatas aerial tubers and examined to be pure by IR spectrum and thin-layer chromatography ${ }^{4}$. d, 1-ABA was generously supplied by Dr. J. W. Cornforth, Shell Research Ltd.

\section{Results and Conclusion}

Effect of $A B A$ on the aerial tuber formation of Begonia plants. Ten plants were treated with $1 \mu \mathrm{g}$ ABA per bud once a day from July 18 to August 18 and subsequently every other day until August 31, 1967. Another set of 10 plants served as control. Around August 20 some flowers began to open, but no difference in number and flowering date was observed between the treated and control lots. Aerial tubers were formed neither in the treated nor control plants by the end of the experiment.

Sprouting of Begonia aerial tubers. Vernalized aerial tubers were incubated from December 13 to 31, 1967 and from March 1 to 16, 1968 in experiments 1 and 2, respectively (Table 2). ABA suppressed sprouting at concentrations of $3 \times 10^{-6}$ and $10^{-5} \mathrm{M}$ (Exp. 1 and 2), and in experiment 2 sprouting was promoted at $10^{-6} \mathrm{M}$. Although in the dark the sprouting percentages were generally lower than those in the light, ABA exhibited similar effects.

Sprouting of Dioscorea aerial tubers. Cut aerial tubers were incubated from March 4 to 22,1968 . In some tubers, eyes began to grow and then entered dormancy again forming processes of tubers. Such tubers were counted as non-sprouted ones (Table 3). Although effects of ABA were weaker, a similar trend of inhibition at $10^{-5} \mathrm{M}$ and promotion at $10^{-6} \mathrm{M}$ was observed as in the case of Begonia tubers.

In intact tubers no appreciable effect of ABA was observed either in the light or in the dark. ABA did not affect rooting of either cut or intact tubers (Table 4). Stability of $A B A$ in Dioscorea tuber tissues. To examine a possible cause for the low responsiveness of Dioscorea tubers to ABA, the recovery of added ABA was determined by incubating $10 \mu \mathrm{g}$ of $\mathrm{ABA}(5 \mathrm{ml}$ of $2 \mu \mathrm{g} / \mathrm{ml}$ solution) with sliced tubers for 
$17.5 \mathrm{hrs}$. The following combinations of $\mathrm{ABA}$ and tuber tissues were designed, i. e. $\mathrm{ABA}$ only, ABA plus tissues, tissues only and the basal medium only (tris- $\mathrm{HCl}$ buffer), and one fourth of the acidic ether extracts from these incubation mixtures were bioassayed by the Avena coleoptile section test. As shown in Fig. 1 no difference in amount was observed between ABA plus tissues and ABA only.

Another one-fourth aliquot of the ether extracts was purified by thin-layer chromatography using solvent system I (Table 1), ABA zone was eluted with ethyl acetate, and the O.R. D.'s of the eluates were recorded. The result in Table 5 confirms that ABA was not decomposed by the tuber tissues.

Table 2. Effect of ABA on the sprouting of cut tubers of Begonia.

\begin{tabular}{|c|c|c|c|c|c|c|}
\hline & & 0 & $\begin{array}{c}\mathrm{ABA} \\
10^{-7}\end{array}$ & $\begin{array}{c}\text { concent } \\
10^{-6}\end{array}$ & $\begin{array}{l}\text { tions }(\mathrm{M}) \\
3 \times 10^{-6}\end{array}$ & $10^{-5}$ \\
\hline \multicolumn{7}{|c|}{ Light incubation } \\
\hline \multirow{2}{*}{ Exp. 1} & $\%$ sprouting & 69 & 70 & 50 & 38 & 42 \\
\hline & No. of viable tubers & 98 & 50 & 50 & 45 & 45 \\
\hline \multirow{2}{*}{ Exp. 2} & $\%$ sprouting & 54 & 54 & 84 & & 35 \\
\hline & No. of viable tubers & 57 & 28 & 32 & & 25 \\
\hline \multicolumn{7}{|c|}{ Dark incubation } \\
\hline \multirow{2}{*}{ Exp. 1} & $\%$ sprouting & 17 & 18 & 15 & 10 & 7 \\
\hline & No. of viable tubers & 93 & 50 & 48 & 42 & 48 \\
\hline \multirow{2}{*}{ Exp. 2} & $\%$ sprouting & 38 & 47 & 65 & & 17 \\
\hline & No. of viable tubers & 61 & 19 & 23 & & 23 \\
\hline
\end{tabular}

Exp. 1, from Dec. 13 to 31, 1967; Exp. 2, March 1 to 16, 1968. In Exp. 1, 50 upper halves of tubers were cultured on a cotton piece in a $9-\mathrm{cm}$ petri dish containing $8 \mathrm{ml}$ of $\mathrm{d}-\mathrm{ABA}$ solution or water. In Exp. 2 a single cut half of a tuber was placed on a cotton piece in each test tube, supplied with $0.5 \mathrm{~m} l$ of $\mathrm{d}-\mathrm{ABA}$ solution or water. In both experiments 50 tubers for each of the $\mathrm{ABA}$ treatments and 100 tubers for the water control were used. Light intensity, 3000 lux, temperature, $25^{\circ}$.

Table 3. Effect of ABA on the sprouting of cut tubers of Dioscorea.

\begin{tabular}{lcccc} 
& \multicolumn{5}{c}{ ABA concentrations $(\mathrm{M})$} & $10^{-5}$ \\
& & & & \\
& & & & \\
Light incubation & 64 & 69 & 73 & 50 \\
\% sprouting & 50 & 48 & 49 & 48 \\
$\quad$ No. of viable tubers & & & & \\
Dark incubation & 72 & 73 & 77 & 67 \\
\% sprouting & 47 & 48 & 47 & 48 \\
$\quad$ No. of viable tubers &
\end{tabular}

Incubation, from March 4 to 22, 1968 at 25․ Light intensity, 3000 lux. Cut tuber pieces were cultured on agar in test tubes. Fifty tubers for each treatment were used. 
Table 4. Effect of ABA on the sprouting of intact Dioscorea aerial tubers.

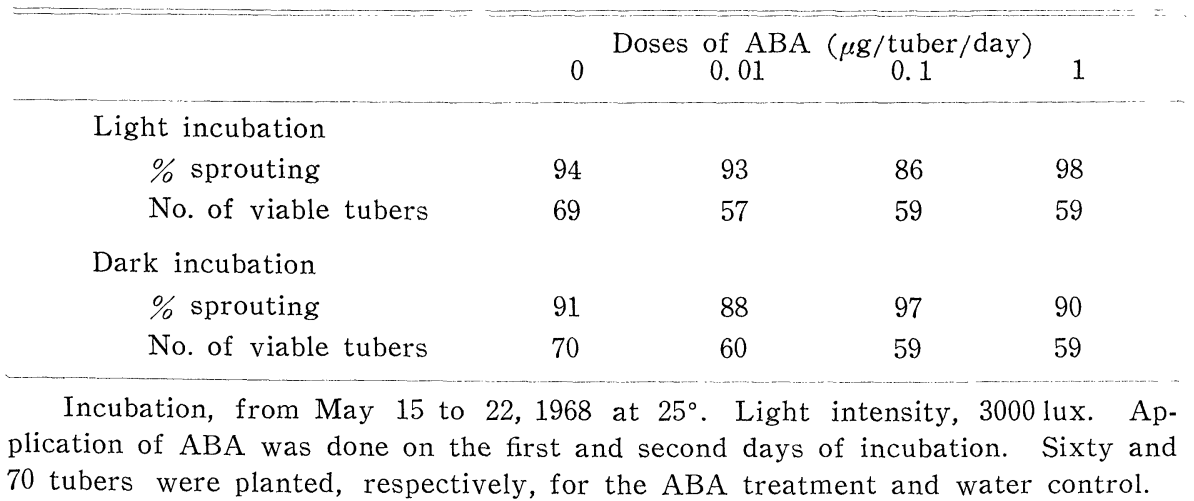

Table 5. Determination of recovery of ABA by optical rotatory dispersion.

\begin{tabular}{lccc} 
& \multicolumn{2}{c}{ Rotations $\left({ }^{\circ}\right)$ at } & $\begin{array}{c}\text { Calculated } \\
\text { amount of ABA* } \\
(\mu \mathrm{g})\end{array}$ \\
without tissues & $245 \mathrm{~m} \mu$ & $297 \mathrm{~m} \mu$ & 1.8 \\
with tissues & 0.018 & not measurable & 2.2 \\
standard $(10 \mu \mathrm{g}$ ABA $)$ & 0.022 & not measurable &
\end{tabular}

* Calculated from the O.R. D.s' at $245 \mathrm{~m} \mu$. The original amount of ABA added in the incubation experiment, $2.5 \mu \mathrm{g}$ each.

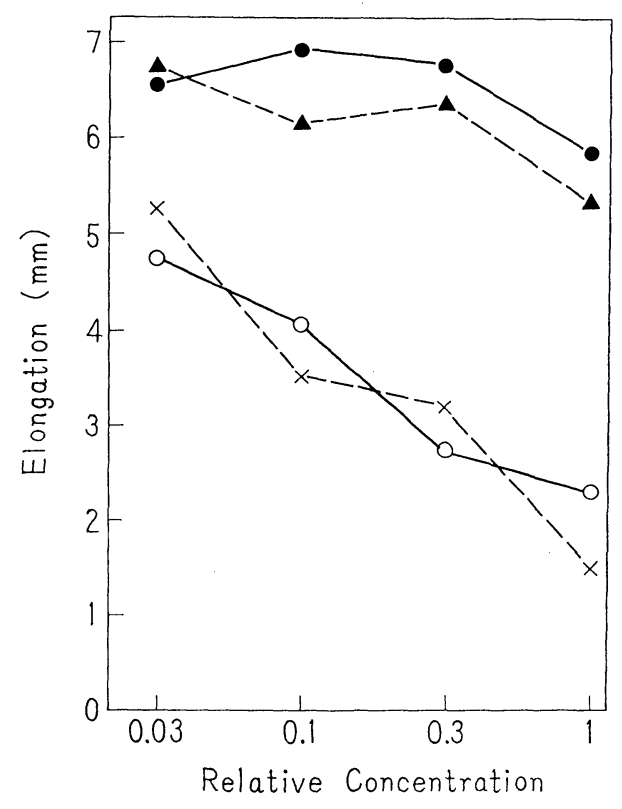

Fig. 1. Recovery of d-ABA incubated with slices of vernalized Dioscorea aerial tubers. Solid circles, basal medium ( $\mathrm{HCl}$-tris buffer) only; solid triangles, tissues only; open circles, ABA only; crosses, ABA plus tissues. Assay of ABA, Avena coleoptile section test. Abscissa, relative concentrations. of test samples in media for Avena coleoptiles, representing as one the concentration obtained when one sixth of the whole extract (see the text) was dissolved in $2.5 \mathrm{~m} l$ of medium. 
In conclusion, the present experiments have shown that ABA suppresses the sprouting of vernalized aerial tubers of $B$. evansiana at high concentrations and, in some experiments, promotes it at low concentrations. Cut aerial tubers of D. batatas also responded to ABA in a similar manner, though slightly. The sprouting of intact tubers of the same species was, however, not affected by the application of ABA, although much larger dose was applied than that used for potato eyes ${ }^{10)}$. Several possible causes for the low responsiveness of Dioscorea tubers may be conceivable, but the experimental results on the ABA recovery (Fig. 1, Table 5) would exclude the possibility that ABA may be decomposed by the tubers.

The present experiments have also shown that ABA is completely ineffective in inducing the formation of aerial tubers in B. evansiana plants growing under long-day conditions. E1-Antably and Wareing ${ }^{14)}$ reported that the acid accelerated the floral initiation in Pharbitis nil and Chenopodium rubrum, but not in Xanthium pensylvanicum and Nicotiana tabacum. The same workers and Hillman ${ }^{15)}$ succeeded in inducing the formation of apical resting buds in Betula pubescens, Acer pseudoplatanus, and Ribes nigrum by ABA. In spite of all our effort we were unable to obtain even small aerial tubers.

We express our thanks to Professor M. Nagao and Dr. N. Okagami, Tohoku University, Sendai, for their advice and help, to Dr. J. W. Cornforth, Shell Research Ltd., Kent, England, for a supply of synthetic ABA, and to Miss Y. Uchida, Faculty of Pharmacy, University of Tokyo for the recording of O.R.D.

\section{References}

1) Esashi, Y., and Nagao, M., Sci. Rep. Tôhoku Univ. 4th Ser. (Biol.) 24 : 81 (1958).

2)—, and ibid. $25: 191$ (1959).

3) Nagao, M., and Mitsui, E., ibid. 25: 199 (1959).

4) Hashimoto, T., Ikai, T., and Tamura, S., Planta 78 : 89 (1968).

5) Chemical Control of plants 3 : 71 (1968).

6) Sankhla, N., and Sankhla, D., Physiol. Plant. 21 : 190 (1968).

7) Sondheimer, E., and Galson, E.C., Plant Physiol. 41 : 1397 (1966).

8) Lipe, W. N., and Crane, J. C., Science 153 : 541 (1966).
9) Bradbeer, J. W., Planta $78: 266$ (1968).

10) Blumenthal-Goldschmidt, S., and Rappaport, L., Plant and Cell Physiol. 6: 601 (1965).

11) Esashi, Y., and Leopold, A.C., Abstract, 6th Int. Conf. Plant Growth Substances: p. 19 (1967).

12) Thomas, T.H., Wareing, P.F., and Robinson, P. M., Nature 205: 1270 (1965).

13) Cornforth, J.W., Milborrow, B. V., and Ryback, G., Nature 210: 627. (1966).

14) El-Antably, H. M. M., and Wareing, P.F., Nature 210: 328 (1966).

15) — , a , a Hillman, J., Planta $73: 74$ (1967).

要

橋本 徹*・田村三郎*：シュウカイドウおよびナガイモの 地上塊茎の発芽におよぼすアブサイシン酸の影響

低温処理によって休眠の打破されたシュウカイドウ（Begonia evansiana）およびナガイモ（Dioscorea batatas）の地上塊茥の発芽に対する d-アブサイシン酸（d-ABA）の影響を調べた．塊茥の上半切片を

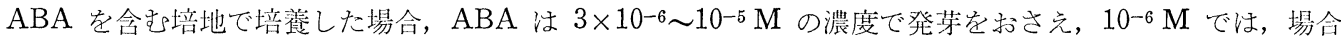
によっては, 発芽を促進した. ナガイモの塊荎切片も, やや微弱ながら同様の反応望示したが, インタクト のナガイモ塊茎は ABA の影響を全然受けなかった。 ナガイモの反応性が低いことの原因を知るために, 
ABA が塊茎組織によって不活性化されるかどうが調べたが，17時間の塊茎スライスとのインキュベ イションによっては，ABA の不活性化は全然認められなかった。

シュウカイドウの腋芽と頂芽を ABA (1 $\mu \mathrm{g} / \mathrm{bud} / \mathrm{day}) て ゙ 44$ 日間にわたって処理したが，長日条件下で 地上塊茎を形成させることはできなかった。 また花芽形成の促進も認められなかった（*東京大学農学部農 芸化学科) 